\title{
Analisis Faktor-Faktor Yang Mempengaruhi Ekspor Komiditi Non Migas Di Indonesia Tahun 1985-2017
}

\author{
Rauzatul Ulfa *a, Devi Andriyani *b \\ *Fakultas Ekonomi dan Bisnis Universitas Malikussaleh \\ a Corresponding author: ansariekp@gmail.com \\ b devisep80@gmail.com
}

\begin{tabular}{l} 
A R T I C L E I N F O R M A T I \\
\hline Keywords: \\
Non-Oil and Gas Exports, \\
Exchange Rate, Economic \\
Growth, Inflation.
\end{tabular}

A B S T R A C T

Keywords:

Non-Oil and Gas Exports, Growth, Inflation.
This study aims to analyze the Factors Affecting Non-Oil and Gas Commodity Exports in Indonesia in 1985-2017. This study uses time series from 1985 to 2017. The study employs the multiple linear regression method. The results of the study partially showed that economic growth had a positive and significant effect on the exports of non-oil and gas commodities in Indonesia, the exchange rate and inflation did not affect the exports of non-oil and gas commodities in Indonesia. Simultaneously, the rate of economic growth and inflation had a positive and significant effect on non-oil and gas commodity exports in Indonesia.

\section{PENDAHULUAN}

Ekspor Indonesia mengalami penurunan pada April 2019 dari Maret 2019 sebesar 10,80 persen. Sementara itu, secara tahunan ekspor Indonesia pada April 2019 anjlok 13,10 persen. Badan Pusat Statistik (BPS) mencatatkan, nilai ekspor pada Maret 2019 sebesar 14,12 miliar dollar AS, sementara pada April tercatat sebesar 12,6 miliar dollar AS. Penurunan ekspor April 2019 disebabkan menurunnya ekspor non migas sebesar 8,68 persen dari 12,98 juta dollar AS jadi 11,8 juta dollar AS. Kondisi perekonomian global yang cenderung melambat dan diikuti harga komoditas yang fluktuatif turut berpengaruh terhadap kinerja ekspor dalam negeri

Ekspor komoditi yang sangat potensial di Indonesia yaitu terdiri dari ekspor Barang Elektronik, karet dan produk karet, sawit, produk hasil hutan, alas kaki, udang, kakao dan Kopi, (BPS, 2019). Negara - negara terbesar yang menjadi tujuan ekspor non migas dari Indonesia yaitu Tiongkok, Amerika Serikat, Jepang, India dan Singapure, ( Databoks.co.id, 2019).

Berikut merupakan perbandingan ekspor migas dan non migas pada tahun 2014 sampai 2016 :

\section{Tabel 1}

Ekspor Migas dan Non Migas di Indonesia.

\begin{tabular}{|l|c|c|c|}
\hline No & Tahun & $\begin{array}{c}\text { Non Migas } \\
\text { (Juta/Us\$) }\end{array}$ & $\begin{array}{c}\text { Migas } \\
\text { (Juta/Us\$) }\end{array}$ \\
\hline 1 & 2014 & 145.961 .200 & 134.718 .900 \\
\hline 2 & 2015 & 131.791 .900 & 118.081 .600 \\
\hline 3 & 2016 & 132.080 .800 & 116.913 .000 \\
\hline
\end{tabular}

Sumber : (BPS, 2019)

Berdasarkan Tabel 1 di atas menunjukkan bahwa perdagangan Indonesia tahun 2014-2016 ekspor non migas Indonesia selalu mengalami kenaikan hal ini terbukti pada tahun 2015 sebesar 131.791.900 Juta/US\$ dan pada tahun 2016 telah mencapai 132.080.800 Juta/US\$. Ekspor non migas masih mendominasi dari nilai total ekspor 
dalam neraca perdagangan. Adapun jenis komiditi yang di ekspor terdiri dari ekspor Barang Elektronik, karet dan produk karet, sawit, produk hasil hutan, alas kaki, udang, kakao dan Kopi. Sementara ekspor migas terjadi penurunan dari tahun 2014 hingga 2016 dimana pada tahun 2014 ekpor migas sebesar 134.718.900 Juta/US\$ hingga 2016 ekspor migas sebesar 116.913.000 Juta/US\$.

Penurunan ekspor migas di sebabkan oleh adanya krisis moneter yang terjadi pada tahun 1998 yang semula 11.622 .500 juta/US\$ pada tahun 1998 turun drastis menjadi 7.872.100 juta/US\$. Disisi lain penurunan ekspor migas juga di sebabkan oleh eksplorasi minyak yang sudah berkurang karena biaya operasi yang menurun.

Dalam meningkatkan ekspor perlu diperhatikan daya saing pada komoditi yang akan di ekspor. Dalam penelitian ini faktor yang digunakan yaitu kurs, pertumbuhan ekonomi dan inflasi. Berikut merupakan perkembangan data beberapa tahun terakhir.

\section{Tabel 2}

Ekspor, Kurs, Pertumbuhan Ekonomi,Inflasi.

\begin{tabular}{|c|c|c|c|c|c|}
\hline No & Tahun & $\begin{array}{c}\text { Ekspor } \\
\text { (Jutaan } \\
\text { Dollar) }\end{array}$ & $\begin{array}{c}\text { Kurs } \\
(\text { Rupiah) }\end{array}$ & $\begin{array}{c}\text { Pertumbuhan } \\
\text { Ekonomi (\%) }\end{array}$ & $\begin{array}{c}\text { Inflasi } \\
(\%)\end{array}$ \\
\hline 1 & 2013 & 149.918 .800 & 12.189 & 5,56 & 8,36 \\
\hline 2 & 2014 & 145.961 .200 & 12.440 & 5,02 & 8,36 \\
\hline 3 & 2015 & 131.791 .900 & 13.795 & 5,05 & 3,35 \\
\hline 4 & 2016 & 132.080 .800 & 14.570 & 5,02 & 3,02 \\
\hline 5 & 2017 & $135,098.900$ & 15.750 & 5,07 & 3,61 \\
\hline
\end{tabular}

Sumber : BPS, (2019)

Kurs merupakan salah satu faktor yang mempengaruhi ekspor non migas di Indonesia. Menurut (Todaro, 2002), kurs adalah harga suatu nilai mata uang terhadap mata uang lainnya. Menurut (Sukirno, 2010) apabila kurs meningkat maka ekspor akan menurun, karena harga-harga diluar negeri dianggap lebih murah daripada harga didalam negeri, dan sebaliknya apabila rupiah melemah maka ekspor non migas akan meningkat, karena harga barang didalam negeri dianggap lebih murah daripada harga barang luar negeri. Namun pada tabel 1.2 di atas menunjukkan bahwa pada tahun 2017 kurs mengalami peningkatan dari tahun sebelumnya, sedangkan ekspor non migas juga ikut mengalami peningkatan dari tahun sebelumnya.

Selain Kurs, Pertumbuhan ekonomi juga menjadi salah satu faktor yang akan berdampak pada naik turunya nilai ekspor non migas. Menurut (Todaro, 2006) pertumbuhan ekonomi adalah kenaikan kapasitas dalam jangka panjang dari negara yang bersangkutan untuk menyediakan berbagai barang ekonomi kepada penduduknya. Ekonomi yang kuat tercermin dari pertumbuhan ekonomi yang tinggi, Tingginya pertumbuhan ekonomi juga terlihat dari tingginya PDB suatu negara. Kenaikan Pendapatan Nasional Indonesia (PDB) akan meningkatkan kemampuan masyarakat untuk melakukan proses produksi barang sehingga Indonesia mampu untuk mengekspor barang ke negara lain (Risma, dkk, 2018). Namun pada Tabel 1.2 di atas menunjukkan bahwa pada tahun 2015 pertumbuhan ekonomi mengalami peningkatan dari tahun sebelumnya, sedangkan ekspor non migas justru mengalami penurunan dari tahun sebelumnya

Nilai ekspor dapat juga dipengaruhi oleh inflasi pada negara tujuan ekspor. (Sukirno, 2010) memberikan definisi bahwa inflasi adalah suatu proses kenaikan harga-harga yang berlaku dalam suatu perekonomian. Jika inflasi meningkat maka harga barang di dalam negara tersebut menjadi mahal. Naiknya inflasi akan menyebabkan biaya produksi semakin tinggi, sehingga tidak efisien 
jika diproduksi. Menurut Sukino, (2010) apabila inflasi menurun maka ekspor barang akan meningkat dan sebaliknya. Namun pada tabel 1.2 di atas menunjukkan bahwa pada tahun 2017 inflasi mengalami peningkatan dari tahun sebelumnya, sedangkan ekspor non migas juga ikut mengalami peningkatan dari tahun sebelumnya.

Dimana penelitian ini bertujuan untuk mengetahui dan menganalisis seberapa besar pengaruh kurs, pertumbuhan ekonomi dan inflasi terhadap ekspor komoditi non migas di Indonesia tahun 19852017. Selanjutnya bagian kedua penelitian ini membahas kajian teoritis variabel-variabel terkait, bagian ke tiga merupakan metodelogi penelitian. Untuk melihat hasil dan pembahasan di bagian ke empat dari penelitian ini. Selanjutnya pembahasan bagian ke lima merupakan kesimpulan dan saran.

\section{TINJAUAN TEORITIS}

\section{Ekspor}

Menurut Amir, (2004) Ekspor adalah upaya dalam menjalankan kegiatan penjulan dari sejumlah komoditas yang kita miliki kepada negara lain sesuai dengan kebijakan yang diberikan oleh pemerintah dengan harapa adanya pembayaran berupa valuta asing.

Menurut Irham dan Yogi, (2003), ekspor yaitu menjual barang-barang ke luar negeri untuk ekspor memperoleh devisa yang akan digunakan bagi penyelenggaraan industri/pembangunan di negaranya, dengan asumsi ekspor yang terjadi haruslah dengan diversifikasi ekspor sehingga bila terjadi kerugian dalam satu macam barang akan dapat diimbangi oleh keunggulan dari komoditi lainnya. Kegiatan ekspor adalah sistem perdagangan dengan cara mengeluarkan barang-barang dari dalam negeri keluar negeri dengan memenuhi ketentuan yang berlaku.

Menurut Upini, Muhammad dan Hamzah ekspor dipengaruhi oleh beberapa faktor seperti: Volume produksi, pendapatan perkapita dan harga. Sedangkan menurut Suardani dan Karmini, (2011) faktor yang mempengaruhi ekspor yaitu: tenaga kerja, produksi dan kurs. Namun menurut Soviandre, Musadieq dan Fanani, (2014) menyatakan bahwa ekspor dipengaruhi oleh produksi domestik, harga dan nilai kurs.

\section{Kurs}

Menurut Todaro, (2002) nilai tukar adalah "Harga suatu nilai mata uang terhadap mata uang lainnya. "Faktor yang mempengaruhi pegerakan nilai kurs merupakan akibat interaksi antara beberapa faktor secara tidak langsung, dengan mengansumsikan faktor lain yang secara langsung. Nilai tukar rupiah dipengaruhi oleh beberapa faktor ekonomi makro, diantaranya berdasarkan kekuatan permintaan dan penawaran uang.

Nilai tukar adalah "Harga suatu nilai mata uang terhadap mata uang lainnya. Faktor yang mempengaruhi pegerakan nilai kurs merupakan akibat interaksi antara beberapa faktor secara tidak langsung, dengan mengansumsikan faktor lain yang secara langsung.

Adapun sistem kurs menurut Irham dan Yogi, (2003) yaitu sebagai berikut :

\section{Kurs Tetap}

Kurs tetap merupakan sistem nilai tukar dimana pemegang otoritas moneter tertinggi suatu negara (Central Bank) menetapkan nilai tukar dalam negeri terhadap negara lain yang ditetapkan pada tingkat tertentu tanpa melihat aktivitas penawaran dan permintaan di pasar uang. Jika dalam perjalanannya penetapan kurs 
tetap mengalami masalah, misalnya terjadi fluktuasi penawaran maupun permintaan yang cukup tinggi maka pemerintah bisa mengendalikannya dengan membeli atau menjual kurs mata uang yang berada dalam devisa negara untuk menjaga agar nilai tukar stabil dan kembali ke kurs tetapnya.

\section{Kurs Mengambang Terkendali}

Penetapan kurs ini tidak sepenuhnya terjadi dari aktivitas pasar valuta. Dalam pasar ini masih ada campur tangan pemerintah melalui alat ekonomi moneter dan fiskal yang ada. Jadi dalam pasar valuta ini tidak murni berasal dari penawaran dan permintaan uang.

3. Kurs Mengambang

Kurs mengambang bebas merupakan suatu sistem ekonomi yang ditujukan bagi suatu negara yang sistem perekonomiannya sudah mapan. Sistim nilai tukar ini akan menyerahkan sleuruhnya kepada pasar untuk mencapai kondisi equilibrium yang sesuai dengan kondisi internal dan eksternal. Jadi dalam sistem nilai tukar ini hampir tidak ada campur tangan pemerintah.

Dalam nilai tukar internasional mengambang depresiasi atau apresiasi nilai mata uang akan mempengaruhi aktivitas ekspor ataupun impor. Apabila nilai tukar terdepresiasi, yaitu melemahnya nilai mata uang dalam negeri terhadap mata uang asing maka akan menyebabkan ekspor semakin meningkat dan impor akan menurun (Sukirno, 2010). Dikarenakan permintaan luar negeri yang meningkat karna harga dalam negri lebih murah sehingga daya saing yang lebih akibat kurs dolar yang meningkat. Hasil penelitian Sandra, (2014) mengenai pengaruh kurs terhadap volume ekspor di New Zealand menunjukan hasil bahwa nilai tukar mempengaruhi volume ekspor.

Hal tersebut didukung dengan penelitian yang dilakukan oleh Makatita, Kumaat Dan Mandei, (2016) bahwa kur berpengaruh positif dan signifikan terhadap ekspor non migas provinsi riau. Hasil penelitian yang dilakukan oleh Suardani dan Karmini, (2011) yang menyimpulkan bahwa kurs mempengaruhi ekspor Kerajinan Perak Di Provinsi Bali. Hasil penelitian Soviandre, Musadieq dan Fanani, (2014) juga menyatakan bahwa kurs berpengaruh positif dan signifikan terhadap ekspor kopi dari Indonesia Ke Amerika Serikat

\section{Pertumbuhan Ekonomi}

Pertumbuhan ekonomi merupakan salah satu indikator yang biasa digunakan untuk mengukur tingkat dari kemakmuran suatu wilayah atau suatu daerah. Menurut Todaro, (2006) pertumbuhan ekonomi adalah kenaikan kapasitas dalam jangka panjang dari negara yang bersangkutan untuk menyediakan berbagai barang ekonomi kepada penduduknya. Kenaikan kapasitas itu sendiri akan dimungkinkan oleh adanya kemajuan atau penyesuaian-penyesuaian tekhnologi, institutional (kelembagaan) dan ideologis terhadap barbagai tuntutan keadaan yang ada.

$$
\text { Menurut Adam Smith, }
$$

perrtumbuhan ekonomi yaitu melihat bahwa suatu perekonomian akan tumbuh dan berkembang jika ada pertambahan penduduk yang akan memperluas pasar serta mendorong spesialisasi. Munculnya spesialisasi akan meningkatkan produktivitas pekerja dan mendorong kemajuan teknologi hingga pertumbuhan ekonomi. 
Pertumbuhan ekonomi Indonesia berdasarkan Produk Domestik Bruto (PDP). Produk Domestik Bruto (PDB) adalah jumlah balas jasa yang diterima oleh faktor-faktor produksi yang turut serta dalam proses produksi di wilayah suatu negara dalam jangka waktu setahun. Jika pertumbuhan ekonomi indonesia mengalami penurunan akan berdampak pada terdepresiasinya rupiah sehingga akan mempengaruhi penawaran akan ekspor jika penawaran ekspor meningkat maka jumlah barang ekspor akan meningkat Sukirno, (2010).

Ekonomi yang kuat tercermin dari pertumbuhan ekonomi yang tinggi, Tingginya pertumbuhan ekonomi juga terlihat dari tingginya PDB suatu negara. Kenaikan Pendapatan Nasional Indonesia (PDB) akan meningkatkan kemampuan masyarakat untuk melakukan proses produksi barang sehingga Indonesia mampu untuk mengekspor barang ke negara lain, Risma, dkk, (2018).

Hasil penelitian yang dilakukan oleh Hamzah, (2016) menunjukkan bahwa pertumbuhan ekonomi Indonesia berpengaruh terhadap ekspor non migas Indonesia ke Jepang. Hal yang sama juga ditunjukkan oleh penelitian Astuti dan Ayuingtyas, (2018) menyatakan bahwa pertumbuhan ekonomi berpengaruh terhadap ekspor. Kemudia penelitian yang dilakukan oleh Asbiantary, Hutagaol dan Asmara, (2016) menyatakan bahwa pertumbuhan ekonomi berpengaruh terhadap ekspor.

\section{Inflasi}

Pengertian Inflasi menurut Sukirno, (2010) memberikan definisi bahwa inflasi adalah suatu proses kenaikan harga-harga yang berlaku dalam suatu perekonomian. Pengertian Inflasi menurut Nanga, (2005) menyatakan bahwa inflasi adalah suatu gejala di mana tingkat harga umum mengalami kenaikan secara terus-menerus. Pengertian Inflasi menurut Raharja dan Manurung, (2004) menyatakan bahwa inflasi adalah gejala kenaikan harga barang-barang yang bersifat umum dan terus menerus. Sedangkan menurut Boediono, (2005) inflasi adalah kecenderungan dari hargaharga untuk menaik secara menyeluruh dan terus menerus.

Menurut Keynes, (1936) bahwa inflasi terjadi karena suatu masyarakat cenderung ingin hidup di luar batas kemampuan ekonominya. Keadaan seperti ini ditunjukkan oleh permintaan masyarakat akan barang-barang yang melebihi jumlah barang- barang yang tersedia

Hasil penelitian Wardhana dan Ali, (2011) yang menyatakan bahwa adanya inflasi dibawah $10 \%$ yang terjadi setiap tahun maka inflasi ini dikategorikan inflasi ringan, yaitu inflasi dibahwa dua digit yang tidak terlalu menimbulkan distorsi pada harga relatif sehingga tidak berdampak pada perubahan ekspor non migas. Hasi penelitian yang dilakukan oleh Permatasari, (2018) menyatakan bahwa inflasi berpengaruh positif dan signifikan terhadap ekspor non migas di Indonesia. Namun berbeda dengan penelitian yang dilakukan oleh Rahayu dan Budhiasa, (2016) Rahayu menyatakan bahwa infalsi berpengaruh negatif dan signifikan terhadap ekspor hasil perikanan di Provindi Bali.

\section{Kerangka Konseptual}

Adapun kerangka konseptual dalam penelitian ini adalah: 


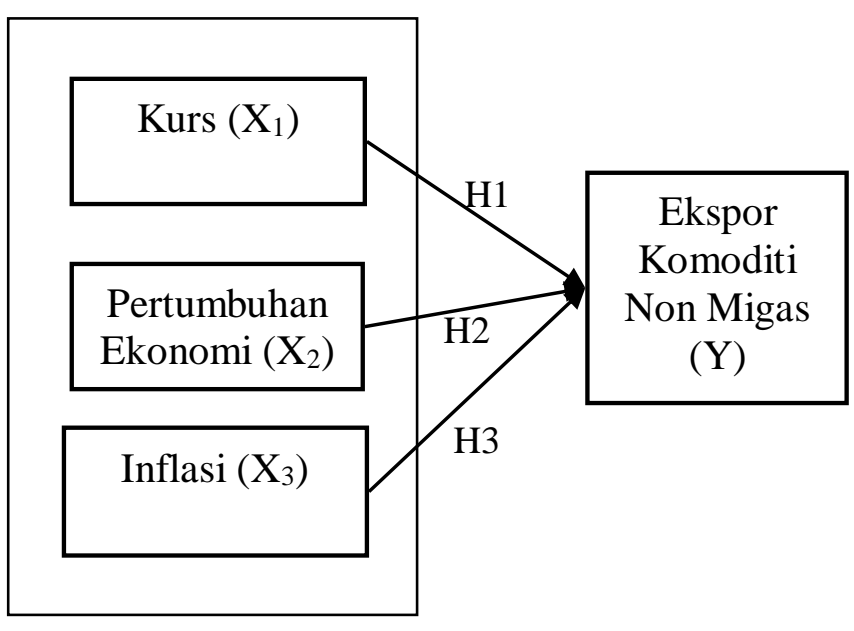

\section{Gambar 1 Kerangka Konseptual}

Dari gambar 1 di atas dapat dilihat bahwa penelitian ini memberi fokus pada pengaruh variabel kurs $(\mathrm{X})$, pertumbuhan ekonomi (X2) dan inflasi (X3) terhadap ekspor komoditi non-migas (Y).

\section{Hipotesis}

Berdasarkan latar belakang penelitian, rumusan masalah dan tujuan penelitian, maka yang menjadi hipotesis dalam penulisan ini ialah antara lain:

$\mathrm{H}_{1}=$ Diduga kurs berpengaruh terhadap ekspor komoditi non-migas di Indonesia.

$\mathrm{H}_{2}=$ Diduga pertumbuhan ekonomi berpengaruh terhadap ekspor komoditi non-migas di Indonesia.

$\mathrm{H}_{3}=$ Diduga inflasi berpengaruh terhadap ekspor komoditi non-migas di Indonesia.

\section{METODE PENELITIAN}

\section{Data dan Sumber Data}

Jenis data yang dipakai dalam penelitian ini adalah Data Sekunder yang digunakan berupa time series, " Data time series adalah data yang dilakukan selama suatu periode/jangka waktu tertentu', Firdaus, (2011). Jenis data dalam penelitian ini adalah data sekunder yang meliputi data yang mengenai nilai tukar yang diperoleh dari Stasistik Ekonomi, Bank Indonesia tahun 19852017, data ekspor non migas, kurs, pertumbuhan ekonomi dan inflasi yang diambil dari data tahunan periode 1985-2017 yang terdapat pada Bank Indonesia dan BPS.

\section{Definisi Operasional Variabel}

\section{Ekpor komoditi non migas (Y)}

Ekspor komoditi non migas adalah menjual barang-barang ke luar negeri yang bukan minyak dan gas . Variabel ini diukur dalam satuan Juta Us\$.

2. $\operatorname{Kurs}\left(X_{1}\right)$

Kurs adalah harga suatu nilai mata uang terhadap mata uang lainnya. Variabel ini diukur dalam Rupiah.

3. Pertumbuhan ekonomi $\left(\mathrm{X}_{2}\right)$

Pertumbuhan ekonomi adalah perubahan tingkat kegiatan ekonomi yang berlaku dari tahun ke tahun. Pertumbuhan ekonomi diukur dalam satuan Persen(\%).

4. Inflasi $\left(\mathrm{X}_{3}\right)$

Proses kenaikan harga-harga barang yang berlaku dalam suatu perekonomian dengan tingkat kenaikan secara terus menerus. Variabel ini diukur dengan \%

\section{Metode Analisis Data}

Analisis data adalah kegiatan mengolah data yang telah terkumpul kemudian dapat menberikan interpretasi pada hasil-hasil tersebut. Metode analisis data yang digunakan dalam penelitian ini adalah Analisis Regresi Linear Berganda. Model regresi digunakan untuk mengasumsikan bahwa terdapat hubungan linier antara variabel kurs $\left(\mathrm{X}_{1}\right)$, pertumbuhan ekonomi $\left(\mathrm{X}_{2}\right)$, inflasi $\left(\mathrm{X}_{3}\right)$ dan ekspor komoditi non migas (Y). Dikarenakan 
perbedaan satuan dari dalam penelitian maka model persamaannya dalam penelitian ini adalah :

$$
\mathrm{LnY}_{\text {it }}=\beta_{0}+\beta_{1} \operatorname{Ln} X_{1 \mathrm{t}}+\beta_{2} \mathrm{X}_{2 \mathrm{t}}+\beta_{3} \mathrm{X}_{3 \mathrm{t}}+\mathrm{e}_{\mathrm{t}}
$$

Keterangan:

$$
\begin{array}{ll}
\mathrm{Y} & =\text { Ekspor komoditi non migas } \\
\beta_{0} & =\text { Constanta } \\
\beta_{1} \beta_{2} \beta_{3} & =\text { Koefesien regrasi } \\
\mathrm{X}_{1} & =\text { Kurs } \\
\mathrm{X}_{2} & =\text { Pertumbuhan ekonomi } \\
\mathrm{X}_{3} & =\text { Inflasi } \\
\mathrm{e} & =\text { Eror term (tingkat kesalahan) } \\
\mathrm{t} & =\text { Waktu }
\end{array}
$$

\section{Uji Normaitas}

normalitas bertujuan untuk menguji apakah dalam model regresi variabel dependen dan variabel independen keduanya mempunyai distribusi normal atau tidak. Model regresi yang baik adalah memiliki distribusi normal atau mendekati normal. Untuk mendeteksi apakah residualnya berdistribusi normal atau tidak dengan membandingkan nilai Jarque Bera dengan $\chi^{2}$ (chisuquare) tabel, yaitu sebagai berikut :

a. Jika nilai Prob $\mathrm{Jb}<5 \%$, maka residualnya berdistribusi tidak normal.

b. Jika nilai Prob $\mathrm{Jb}>5 \%$, maka residualnya berdistribusi normal.

\section{Uji Asumsi Klasik}

\section{Uji Multikolinieritas}

Uji multikolinieritas adalah situasi adanya korelasi variabel-variabel bebas diantara satu dengan yang lain. Uji multikolinearitas adalah salah satu pengujian di dalam asumsi klasik yang berguna untuk melihat apakah variabel-variabel indepeden di dalam penelitian memiliki hubungan atau tidak. Gujarati, (2012) mengatakan bahwa model regresi linear berganda yang baik tidak memiliki hubungan di antara variabel-variabel bebasnya. Uji multikolinieritas dapat dilihat melalui nilai $r$ korelasi. Tidak terjadi multikolinieritas apabila nilai $r$ korelasi di dibawah 0,8 .

\section{Uji Autokorelasi}

Autokorelasi yaitu adanya hubungan antara kesalahan pengganggu yang muncul pada data runtun waktu (time series). Dalam penaksiran model regresi linier mengandung asumsi bahwa tidak terdapat autokorelasi antara kesalahan pengganggu. Menurut Gujarati, (2012) keputusan pengambilan autokorelasi yaitu :

a. Apabila nilai Obs*R-Square $<X^{2}$ (chi-square) maka tidak terjadi autokorelasi.

b. Apabila nilai Obs*R-Square $>X^{2}$ (chi-square) maka tidak terjadi autokorelasi.

Selanjutnya hasil uji autokorelasi juga dapat di lihat dengan membandingkan probabilitas Chi-Squared dan nilai signifikan 5\% yaitu sebagai berikut :

a. Apabila nilai Prob Chi-Squared $<5 \%$, maka terjadi autokorelasi.

b. Apabila nilai Prob Chi-Squared > 5\%, maka tidak terjadi autokorelasi.

\section{Uji Heteroskedastisitas}

Uji heteroskedastisitas bertujuan untuk menguji apakah dalam model regresi terjadi ketidaksamaan variance dari residual satu pengamatan ke pengamatan lain. Menurut Gujarati, (2012) Keputusan terjadi atau tidaknya heteroskedastisitas pada model regresi linier dapat dilihat melalui chi Square hitung $\left(\mathrm{X}^{2}\right)$ lebih kecil dari chi squared $\left(\mathrm{X}^{2}\right)$ tabel pada tingkat $\alpha=5 \%$. 
Untuk mendeteksi ada tidaknya heteroskedastisita maka dengan membandingkan nilai R-squared dan tabel chi-square.

a. Jika nilai Obs*R-squared > chi-square tabel, maka tidak lolos dari uji heteroskedastisitas.

b. Jika nilai Obs*R-squared < chi-square tabel, maka lolos dari uji heteroskedastisitas.

\section{Pengujian Hipotesis}

Setelah dilakukan pengukuran variable dalam penelitian ini, maka dilakukan pengujian hipotesis. Untuk melakukan keputusan menerima atau menolak hipotesis yang diajukan, maka perlu dilakukan pengujian secara statistik.

1. Uji t

Uji t dilakukan untuk melihat pengaruh variabel independen terhadap variabel dependen secara parsial. Bila $t_{\text {hitung }}>t_{\text {tabel }}$ dengan tingkat signifikan 5\%, dan jika $t_{\text {hitung }}<\mathrm{t}_{\text {tabel }}$ dengan tingkat signifikan 5\%, maka dapat disimpulkan bahwa variabel independen tidak berpengaruh terhadap variabel dependen.

\section{Uji F}

Pengujian ini bertujuan untuk mengetahui pengaruh variabel independen secara bersamasama terhadap variabel dependen dengan melihat nilai signifikansi $F$. Bila $f_{\text {hitung }}>f_{\text {tabel }}$ dengan tingkat signifikan 5\%, maka dapat disimpulkan bahwa secara simultan variabel independen berpengaruh signifikan terhadap variabel dependen.

\section{HASIL PENELITIAN DAN PEMBAHASAN}

\section{Uji Normalitas}

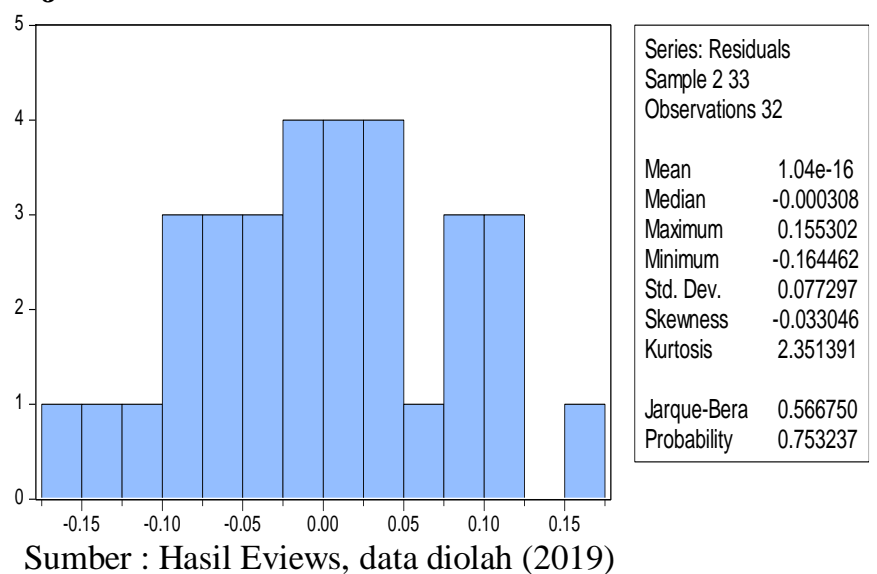

Gambar 2

Hasil Uji Normalitas

Berdasarkan gambar di atas hasil uji normalitas menunjukkan bahwa nilai JB sebesar $0,56<9,49$ sehingga dapat disimpulkan bahwa data terdistribusi normal. Hasil dari uji normalitas menunjukkan bahwa nilai Prob JB > 0,05 yaitu sebesar 0,753>0,05 maka dapat disimpulkan bahwa residual dalam penelitian ini sudah terdistribusi dengan normal.

\section{Uji Asumsi Klasik}

Uji Multikolinieritas

Tabel 3

Hasil Uji Multikolinieritas

\begin{tabular}{|l|c|c|c|}
\hline & Log Kurs & $\begin{array}{c}\text { Pertumbuhan } \\
\text { Ekonomi }\end{array}$ & Inflasi \\
\hline Log Kurs & 1 & 0,547553 & $-0,072737$ \\
\hline $\begin{array}{l}\text { Pertumbuhan } \\
\text { Ekonomi }\end{array}$ & 0,547553 & 1 & $-0,294619$ \\
\hline Inflasi & $-0,072737$ & $-0,294619$ & 1 \\
\hline
\end{tabular}

Sumber : Hasil eviews, 2019

Berdasarkan Tabel 3 dapat dilihat tidak terdapat sel antar variabel bebas yang memiliki nilai di atas 0,8, maka dapat dikatakan bahwa seluruh variabel bebas dalam penelitian ini tidak saling berkorelasi dan penelitian ini bebas dari gejala multikolinearitas. 
Uji Autokorelasi

Tabel 4

\section{Uji Autokorelasi}

Breusch-Godfrey Serial Correlation LM

Test:

\begin{tabular}{lcc}
\hline \hline F-statistic & $\begin{array}{c}1.819768 \text { Prob. }(2,25) \\
\text { Prob. Chi- }\end{array}$ & 0.1829 \\
Obs*R-squared & 4.066586Square(2) & 0.1309 \\
\hline \hline
\end{tabular}

Sumber : Data diolah (2019)

Berdasarkan hasil out put $O b s * \mathrm{R}$-squared sebesar 4,06 di bandingkan dengan Chi-Squared tabel pada df (2) sebesar 5,99, maka 4,06 $<5,99$ berarti data muncul sudah berbeda sehingga tidak terjadi autokorelasi dalam penelitian. Hal ini juga dapat dilihat dari Pro. Chi Square lebih besar dari 0,05 yaitu 0,130 .

\section{Uji Heteroskedastisitas}

\section{Tabel 5}

\section{Uji Heteroskedastisitas}

Heteroskedasticity Test: White

\begin{tabular}{llll}
\hline \hline F-statistic & 0.648415 & Prob. F(4,27) & 0.6329 \\
Obs*R-squared & 2.804556 & Prob. Chi-Square(4) & 0.5910 \\
Scaled explained SS & 1.349096 & Prob. Chi-Square(4) & 0.8530 \\
\hline
\end{tabular}

Sumber : Data diolah, (2019)

Dari hasi tabel 5 di atas dapat dilihat bahwa nilai obs* R-square untuk hasil estimasi uji white adalah sebesar 2,80 dan nilai $\chi^{2}$ tabel dengan derajat kepercayaan 5\% dan df (4) adalah 9,49 karena nilai Obs*R-squared 2,80 $<$ 9,49 maka dapat disimpulkan bahwa model diatas lolos dari heteroskedastisitas. Hal ini juga dapat dilihat dari probabilitas Chi-Squared sebesar 0,591, nilai tersebut $0,591>0,05$.

\section{Analisis Regresi Linier Beerganda}

Tabel 6

\section{Hasil Analisis Regresi Linier Berganda}

\begin{tabular}{lcccc}
\hline \hline Variable & Coefficient & Std. Error & t-Statistic & Prob. \\
\hline \hline C & 1.901794 & 0.499215 & 3.809568 & 0.0007 \\
LOG(X1) & 0.009564 & 0.129898 & 0.073630 & 0.9418
\end{tabular}

\begin{tabular}{lllll} 
X2 & 0.090255 & 0.022793 & 3.959725 & 0.0005 \\
X3 & 0.000311 & 0.001241 & 0.250489 & 0.8041 \\
\hline \hline R-squared & 0.992788 & & & \\
Adjusted R- & & & & \\
squared & 0.991720 & & & \\
F-statistic & 929.2484 & & \\
Prob(F- & & & \\
statistic) & 0.000000 & & \\
Durbin- & 2.206720 & & \\
Watson stat & 2.20 & \\
\hline \hline
\end{tabular}

Sumber : Eviews 8, data diolah (2019)

Dari tabel 6 di atas maka model regresi linier berganda adalah sebagai berikut :

$\log Y=1,901794+0,009564 \log X_{1}+0.090255$ $\mathrm{X}_{2}+0.000311 \mathrm{X}_{3}$

Dari hasil diatas dapat di interpretasi hasil analisis regresi linier berganda yaitu sebagai berikut :

1. Constanta sebesar 1,901794 menunjukkan apabila kurs $\left(\mathrm{X}_{1}\right)$, pertumbuhan ekonomi $\left(\mathrm{X}_{2}\right)$ dan inflasi $\left(\mathrm{X}_{3}\right)$ bernilai konstant maka ekspor komoditi non migas (Y) juga akan konstan sebesar $1,901794 \%$.

2. Koefisien variabel kurs $\left(X_{1}\right)$ mempunyai nilai sebesar 0,009564, Hal ini menunjukkan hubungan yang positif. Artinya apabila kurs $\left(\mathrm{X}_{1}\right)$ meningkat $1 \%$ maka ekspor komoditi non migas (Y) juga akan meningkat sebesar $0,009 \%$ dengan asumsi pertumbuhan ekonomi dan inflasi konstan.

3. Koefisien variabel pertumbuhan ekonomi $\left(\mathrm{X}_{2}\right)$ mempunyai nilai sebesar 0,090255, Hal ini menunjukkan hubungan yang positif. Artinya apabila pertumbuhan ekonomi $\left(\mathrm{X}_{2}\right)$ meningkat $1 \%$ maka ekspor komoditi non migas (Y) juga akan meningkat sebesar 0,090\% dengan asumsi kurs dan inflasi konstan.

4. Koefisien variabel inflasi $\left(\mathrm{X}_{2}\right)$ mempunyai nilai sebesar 0.000311, Hal ini menunjukkan hubungan yang positif. Artinya apabila inflasi 
$\left(\mathrm{X}_{2}\right)$ meningkat $1 \%$ maka ekspor komoditi non migas (Y) akan meningkat sebesar 0,0003\% dengan asumsi pertumbuhan ekonomi dan kurs konstan.

\section{Pengujian Hipotesis}

\section{Pembahasan Uji t}

Berdasarkan hasil pengujian secara parsial pada tabel 6 dapat dijelaskan bahwa :

1. Variabel kurs $\left(X_{1}\right)$ tidak berpengaruh terhadap variabel ekspor komoditi non migas (Y). Hal ini didasarkan pada nilai $\mathrm{t}$ hitung $>\mathrm{t}$ tabel yakni $0,0736<1,697$ maka terima $H_{1}$. Hal ini juga bisa dilihat dari probabilitas hitung $>\mathrm{p}-$ value atau $0.941>0.10$.

2. Variabel pertumbuhan ekonomi $\left(\mathrm{X}_{2}\right)$ berpengaruh secara signifikan dan positif terhadap variabel ekspor komoditi non migas (Y). Hal ini didasarkan pada nilai $\mathrm{t}$ hitung $>\mathrm{t}$ tabel yakni 3,959>2,749 maka terima $\mathrm{H}_{2}$. Hal ini juga bisa dilihat dari probabilitas hitung $<\mathrm{p}-$ value atau $0.000<0.01$.

3. Variabel inflasi $\left(\mathrm{X}_{3}\right)$ tidak berpengaruh terhadap variabel ekspor komoditi non migas (Y). Hal ini didasarkan pada nilai $\mathrm{t}_{\text {hitung }}<\mathrm{t}$ tabel yakni $0,250<1,697$ maka tolak $\mathrm{H}_{3}$. Hal ini juga bisa dilihat dari probabilitas hitung $>\mathrm{p}-$ value atau $0.804>0.10$.

\section{Pembahasan Uji F}

Berdasarkan hasil pengujian pada tabel di atas maka dapat dilihat bahwa nilai $F_{\text {hitung }}$ sebesar 929,248 dengan probabilitas sebesar 0,000, sedangkan $\mathrm{f}_{\text {tabel }}$ pada $\mathrm{df}=(\mathrm{k}-1)(\mathrm{n}-\mathrm{k})=(3-1)(33-3)$ $=$ (2) (30) yaitu sebesar 5,390 dari $\alpha=1 \%$, maka $F_{\text {hitung }}>F_{\text {tabel }}$ yaitu 929,248 $>$ 5,390. Maka dapat disimpulkan bahwa $\mathrm{H}_{4}$ diterima artinya secara simultan kurs $\left(\mathrm{X}_{1}\right)$ pertumbuhan ekonomi $\left(\mathrm{X}_{2}\right)$ dan inflasi $\left(\mathrm{X}_{3}\right)$ berpengaruh signifikan dan positif terhadap ekspor komoditi non migas (Y).

\section{Pembahasan}

\section{Pengaruh Kurs Terhadap Ekspor Komoditi} Non Migas

Hasil dari penelitian ini menunjukkan bahwa kurs $\left(\mathrm{X}_{1}\right)$ tidak berpengaruh terhadap ekspor komoditi non migas (Y) di Indonesia. Hal tersebut dikarenakan permintaan dari luar negeri yang meningkat karena harga dalam negeri lebih murah sehingga memiliki daya saing yang lebih akibat kurs dollar yang meningkat. di sisi lain juga disebabkan karena ketergantungan negara pengimpor terhadap hasil perikanan di provinsi bali dikarenakan jarak yang lebih dekat.

\section{Pengaruh Pertumbuhan Ekonomi Terhadap Ekspor Komoditi Non Migas}

Hasil dari penelitian ini menunjukkan bahwa Pertumbuhan ekonomi $\left(\mathrm{X}_{2}\right)$ berpengaruh positif terhadap ekspor komoditi non migas (Y) di Indonesia. Hal ini menunjukkan bahwa apabila pertumbuhan ekonomi suatu negara meningkat maka jumlah barang yang akan di ekspor juga semakin meningkat. Hasil penelitian ini sejalan dengan teori yang dikemukakan oleh Risma, dkk, (2018) dimana Ekonomi yang kuat tercermin dari pertumbuhan ekonomi yang tinggi, Tingginya pertumbuhan ekonomi juga terlihat dari tingginya PDB suatu negara. Kenaikan Pendapatan Nasional Indonesia (PDB) akan meningkatkan kemampuan masyarakat untuk melakukan proses produksi barang sehingga Indonesia mampu untuk mengekspor barang ke negara lain. 
Jika pertumbuhan ekonomi indonesia mengalami penurunan akan berdampak pada terdepresiasinya rupiah sehingga akan mempengaruhi penawaran akan ekspor jika penawaran ekspor meningkat maka jumlah barang ekspor akan meningkat Sukirno, (2010).

Hasil penelitian ini sejalan dengan penelitiann yang dilakukan oleh Upini dan Hamzah, (2016) menunjukkan bahwa pertumbuhan ekonomi Indonesia berpengaruh terhadap ekspor non migas Indonesia ke Jepang.

\section{Pengaruh Inflasi Terhadap Ekspor Komoditi} Non Migas

Hasil dari penelitian ini menunjukkan bahwa Inflasi $\left(\mathrm{X}_{3}\right)$ tidak berpengaruh terhadap ekspor komoditi non migas (Y) di Indonesia. Hal ini menunjukkan bahwa apabila inflasi mengalami peningkatan maka ekspor komoditi non migas akan semakin berkurang.

Hasil penelitian ini mendukung teori Wardhana dan Ali, (2011) yang menyatakan bahwa adanya inflasi dibawah $10 \%$ yang terjadi setiap tahun maka inflasi ini dikategorikan inflasi ringan, yaitu inflasi dibahwa dua digit yang tidak terlalu menimbulkan distorsi pada harga relatif sehingga tidak berdampak pada perubahan ekspor non migas.

\section{KESIMPULAN DAN SARAN}

\section{Kesimpulan}

Berdasarkan hasil penelitian dan pembahasan, maka peneliti mengemukakan kesimpulan sebagai berikut :
1. Secara parsial kurs $\left(X_{1}\right)$ berpengaruh positif dan signifikan terhadap ekspor komoditi non migas di Indonesia tahun 1985-2017.

2. Secara parsial pertumbuhan ekonomi $\left(\mathrm{X}_{2}\right)$ berpengaruh positif dan signifikan terhadap ekspor komoditi non migas di Indonesia tahun 1985-2017.

3. Secara parsial inflasi $\left(\mathrm{X}_{3}\right)$ tidak berpengaruh terhadap ekspor komoditi non migas di Indonesia tahun 1985-2017.

4. Secara bersama-sama kurs pertumbuhan ekonomi dan inflasi berpengaruh positif dan signifikan terhadap ekspor komoditi non migas di Indonesia tahun 1985-2017. Dan besarnya pengaruh adalah sebesar 0,9137 dan dipengaruhi oleh variabel lain di luar model ini adalah sebesar 0,0863 .

\section{Saran}

Adapun saran yang dapat diberikan peneliti dalam penelitian ini adalah sebagai berikut :

1. Hendaknya pemerintah dapat mempertahankan nilai tukar rupiah dalam batas yang wajar, sebab jika nilai rupiah terlalu tinggi maka ekspor dapat berkurang.

2. Hasil analisis yang dilakukan pada penelitian ini masih bersifat agregat dan masih menunjukkan adanya faktor-faktor lain yang tidak terdapat pada model persamaan yang digunakan. Untuk penelitian selanjutnya dapat memasukkan faktor-faktor lain seperti harga pupuk urea dunia, konsumsi pupuk urea dunia dan kebijakan perdagangan pupuk urea dunia. 


\section{DAFTAR PUSTAKA}

Amir M.S. (2003). Ekspor Impor Teori dan Penerapannya. Cetakan Kedelapan. Penerbit. Lembaga Manajemen PPM, Jakarta Pusat.

Arifin, Immamul Dan Gina Hadi W. (2009). Membuka Cakrawala Ekonomi. Grafindo. Bandung.

Adisasmita, R. (2010). Pembangunan Kawasan dan Tata Ruang. Yogyakarta: Graha Ilmu.

Abdurohman dan R. Zuladin (2003), "Performance Of Indonesia's Key Non-Oil Export During The Crisis: Value Vs Quantity Movement."Kajian Ekonomi dan Keuangan, Vol.6-No.4

Anindita dan Michael, (2008) Bisnis dan Perdagangan Internasional. Edisi Pertama. ANDI, Yogyakarta.

Boediono, Gideon S.B. (2005) Kualitas Laba: Studi Pengaruh Mekanisme Corporate Governance dan Dampak Manajemen Laba Dengan Menggunakan Analisis Jalur. Simposium Nasional Akuntansi VIII. Solo

Firdaus A.Dunia. (2013), Pengantar Akuntansi, Edisi 4. Jakarta: Fakultas Ekonomi.

Ghozali, Imam. (2014). Aplikasi Analisis Mulitivariate Dengan Program Spss. Edisi Ketiga. Universitas Di Penegoro. Semarang.

Hadi Hamdy (2004) Teori dan Kebijakan Perdagangan Ekonomi Internasional. Jakarta : Ghalia Indonesia

Irham dan Yogi. (2003). Ekspor di Indonesia. Cetakan Pertama. Pustaka Binaman. Pressindo. Jakarta.

Julius.R, (2011), Bank dan Lembaga Keuangan Lain. Jakarta: Salemba Empat

Jhingan, M.L. (2006) Ekonomi Pembangunan dan Perencanaan. Terjemahan oleh D. Guritno.Edisi Pertama. Jakarta: PT. Raja Grafindo Persada
Kahfi (2016) Determinants Of Indonesia's Exports Of Manufactured Products: A Panel Data Analysis

Makatita, Kumat dan Mande (2016) Analisis Faktor-Faktor Yang Mempengaruhi Ekspor Tepung Kelapa Sulawesi Utara. AgriSosioEkonomi Unsrat, Volume 12 Nomor 2A.

Mankiw, N.Gregory. (2006) Teori Makroekonomi Edisi Kelima. (Terjemahan Imam Nurmawan). New York: Worth Publisher, 41 Medison Avenue.

Marlinda (2015) Faktor-Faktor Yang Mempengaruhi Ekspor Impor Indonesia Periode 2008-2013

Maygirtasari, Yulianto dan MAwardi (2015) Faktor-Faktor Yang Mempengaruhi Volume Ekspor Crude Palm Oil (Cpo) Indonesia Jurnal Administrasi Bisnis (JAB)|Vol. 25 No. 2

Ma'ruf dan Latri Wihastuti. (2008). Pertumbuhan Ekonomi Indonesia : Determinan dan Prosfeknya. Jurnal Ekonomi dan Studi Pembangunan Vol-9, no-1 Arpil 2008 : 4445.

Murni, Dan Y.Mandagie (2013) Roa, Roe, Npm Pengaruhnyaterhadapdividen Payout Ratio(Pada Perusahaan Perbankkan Dan Financial Institusi Yang Terdaftar Dibei Periode 2010-2012)Jurnal Emba, Vol.2, No.2:1406-1416.

Nanga, Muana. (2005). Makro Ekonomi, Teori, Masalah, Dan Kebijakan. Edisi Kedua. Jakarta: Pt Raja Grafindo Persada.

Natsir, M. (2014). Metode Penelitian. Edisi Kelima. Jakarta: Ghalia Indonesia

Oktavia (2013) Pengaruh Manajemen Laba, Rasio Likuiditas, Rasio Leverage, Rasio Aktivitas, Rasio Profitabilitas Dan Firm Sizeterhadap Returnsaham (Studi Pada Perusahaan Telekomunikasi Yang Go Public Di Bursa Efek Indonesia Periode 2010-2014). EProceeding Of Management. Vol.3, No.3. Issn: 2355-935. 
Panjaitan, R. (2011). Manajemen. Jakarta: Sagung Seto

Permatasari (2018) Analisis Pengaruh Kurs, Inflasi, Dan Investasi Terhadap Nilai Ekspor Nonmigas Di Indonesia Tahun 2000-2016. Universitas Muhammadiyah Surakarta.

Rahardja, Prathama. Manurung, Mandala. (2006). Teori Ekonomi Mikro Suatu Pengantar, Edisi Ketiga, Jakarta; Lembaga Penerbit Fakultas Ekonomi Universitas Indonesia.

Risma, Zulham dan Dawod (2018) Pengaruh Suku Bunga, Produk Domestik Bruto Dan Nilai Tukar Terhadap Ekspor Di Indonesia. Volume 4 Nomor 2, September 2018

Suardani dan Karmini (2011) Analisis FaktorFaktor Yang Mempengaruhi Ekspor Kerajinan Perak Di Provinsi Bali, E-Jurnal Ekonomi Pembangunan Universitas Udayana Vol.6 No 11.

Soviandre, Musadieq dan Fanani (2014) FaktorFaktor Yang Mempengaruhi Volume Ekspor Kopi Dari Indonesia Ke Amerika Serikat (Studi pada Volume Ekspor Kopi Periode Tahun 2010-2012) Jurnal Administrasi Bisnis (JAB)|Vol. 14 No. 2

Sukirno, (2010). Makro Ekonomi. Edisi Ke-1, Rajawali Pers, Jakarta

Situmeang, Chandra (2010) Manajemen Keuangan Edisi Revisi Iii. Medan: Universitas Negeri Medan.

Sukwiaty (2005). Ekonomi 2. Jakarta: Yudistira.

Tadoro, Michael P. (2002) Ilmu Ekonomi Bagi Negara Sedang Berkembang. Buku 1 . Jakarta: Akamemika Pressindo.

Triyoso, Bambang. (2004). Analisis Kausalitas Antara Ekspor dan Pertumbuhan Ekonomi, Jakarta

Upini, Muhammad dan Hamzah (2016) Analisis Faktor-Faktor Yang Mempengaruhi Volume Ekspor Pupuk Urea Indonesia Jurnal Visioner \& Strategis Volume 5, Nomor 1.
Wardhana dan Ali. (2011). Analisis faktor-faktor yang mempengaruhi ekspor nonmigas Indonesia ke Singapura tahun 1990-2010. Universitas Lambung Makurat.Vol.12 No 2 Oktober 2011

Widarjono, Agus (2009), Ekonometrika : Panduan Eviews, Yogyakarta, YKPN

Winardi. (2006) Ekonomi Internasional. Erlangga, Jakarta. 